\title{
Simulasi Perancangan Filter Analog dengan Respon Chebyshev
}

\author{
Rustamaji, Arsyad Ramadhan Darlis, Solihin \\ Teknik Elektro Institut Teknologi Nasional \\ Email : solihin.suparman@yahoo.co.id
}

\begin{abstract}
ABSTRAK
Dalam suatu sistem komunikasi penggunaan rangkaian filter sangat penting. Salah satu cara untuk memudahkan dalam perancangan sebuah filter dilakukanlah teknik simulasi. Penelitian ini bertujuan untuk merancang simulasi yang menghasilkan respon filter jenis chebyshev serta menghasilkan nilai komponen induktor (L) dan kapasitor (C) yang dibutuhkan untuk merangkai filter. Simulasi yang dirancang pada penelitian ini menggunakan Graphical User Interface (GUI). Dari simulasi yang dilakukan, didapatkan respon Chebyshev pada low pass filter, high pass filter, band pass filter, dan band stop filter sudah sesuai dengan input yang dimasukkan ke dalam parameter program dan sesuai dengan teori respon filter Chebyshev. Hasil Simulasi dari rangkaian band pass filter dan band stop filter dengan menggunakan Electronic Workbench (EWB), menunjukkan respon dengan pergeseran frekuensi sebesar 0,1 kHz lebih tinggi dari frekuensi yang diharapkan.
\end{abstract}

Kata Kunci :filter, Chebyshev, band, respon frekuensi.

\begin{abstract}
On communication system using filter is very important. One way to simplify the design of filter undertaken a simulation technique. This research aims to design a simulation that generates the filter response of chebyshev and generate the value component of the inductor ( $L$ ) and capacitor (C) that needed for constructing the filter. This Simulation using Graphical User Interface (GUI). From result simulation, response in low pass filter, high pass filter, band pass filter, band stop filter and is in compliance with the input entered into the program and in accordance with the theory of Chebyshev filter response. The simulation of the band pass filter and bands stop filter by using electronic workbench ( $E W B$ ), show a response with shifts frequency of $0.1 \mathrm{khz}$ higher than frequency expected.
\end{abstract}

Keywords: filter, Chebyshev, band, response 


\section{PENDAHULUAN}

Dalam suatu sistem komunikasi, penggunaan rangkaian filter sangat penting pada bagian pengirim maupun penerima. Filter adalah suatu sistem yang berfungsi menyaring sinyal yang masuk kedalam suatu sistem atau rangkaian lain, dan menghasilkan sinyal dengan spektrum frekuensi yang dapat diatur sesuai dengan kebutuhan. Salah satu jenis respon filter analog yang sering digunakan adalah respon chebyshev. Respon chebyshev adalah Respon filter yang memiliki sebuah roll-off yang curam dengan membiarkan ripple pada bagian tertentu dari respon frekuensi. (steven, 1997)

Dalam perancangan sebuah filter dapat digunakan simulasi perancangan melalui perangkat lunak yang bertujuan untuk mempermudah dalam penentuan desain rangkaian yang akan digunakan untuk merangkai sebuah filter dan dapat menjelaskan karakteristik dan respon dari suatu filter. Salah satu perangkat lunak yang dapat melakukan simulasi perancangan tersebut adalah Matlab 7.9. (saputro, 2009). Perancangan program simulasi ini dilakukan secara manual serta mengumpulkan bahan-bahan referensi dan perangkat lunak yang akan digunakan dalam perancangan, kemudian merancang interface pemograman berupa desain grafisnya, kemudian menuliskan kode-kode perintah ataupun formula yang tepat untuk menghubungkan obyek maupun kode program berdasarkan kombinasi dari perintah Matlab versi 7 tersebut, dan terakhir menyimpan file proses pembuatan aplikasi dalam direktori tersendiri. Hal ini sangat penting karena Matlab menggunakan banyak file dengan nama yang berbeda meskipun aplikasi yang dibuat merupakan satu kesatuan. Sehingga tidak terjadi kesalahan dalam penggunaan aplikasi program simulasi tersebut.

Sebelumnya simulasi perancangan filter analog dengan respon butterworth, telah dilakukan oleh Leo Tampubolon (Tampubolon, 2012) namun pada bagian program simulasi untuk frekuensi cut-off untuk respon magnitude maksimal hingga 2 rad/s, dan orde dari 1 hingga 7 serta pada perhitungan nilai komponen $(L)$ dan kapasitor $(C)$ frekuensi cut-off hanya pada $50 \mathrm{MHz}$. Penelitian ini merupakan salah satu bentuk pengembangan dengan respon yang berbeda yaitu chebyshev. Frekuensi dan orde pada respon magnitude tidak dibatasi dan frekuensi dapat diatur sesuai dengan kebutuhan pada perhitungan nilai komponen induktor (L) dan kapasitor (C).

Dalam penelitian ini dilakukan perancangan simulasi filter analog dengan respon Chebyshev pada Matlab 7.9. dan melakukan perhitungan untuk mendapatkan nilai kapasitor (C) dan induktor (L) untuk merancang beberapa rangkaian filter seperti low pass filter (LPF), high pass filter (HPF), band pass filter (BPF), dan band stop filter (BSF).

\section{METODOLOGI PENELITIAN}

\subsection{Perancangan Simulasi}

Simulasi untuk perancangan filter analog dengan respon Chebyshev ini menggunakan Graphical User Interface (GUI) Designer yang terdapat pada software (perangkat lunak) Matlab yang berfungsi untuk merancang tampilan yang digunakan oleh user (pengguna). (sugiharto, 2006) Gambar 1 menunjukkan flowchart perancangan simulasi untuk memudahkan memahami alur perancangan simulasi dari penelitian ini. 


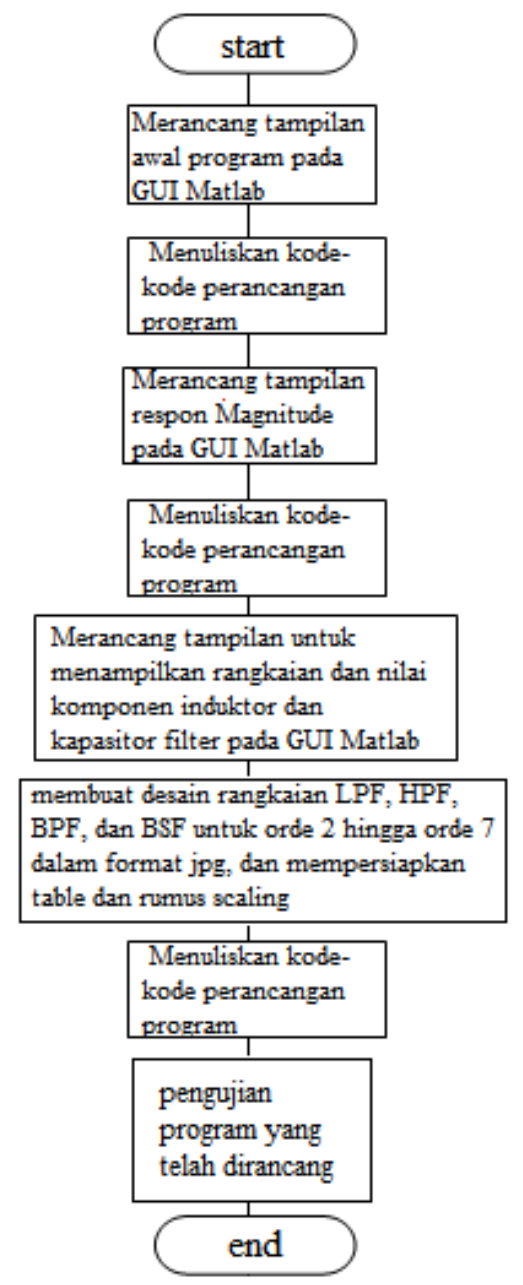

Gambar 1. Flowchart perancangan simulasi

Dari Gambar 1, Flowchart perancangan simulasi dimulai dengan start yang artinya telah masuk ke dalam proses pembuatan awal GUI (Graphic User Interface) dalam program GUI blank dengan tampilan yang masih kosong. Selanjutnya merancang tampilan awal untuk program perancangan simulasi filter analog dengan respon chebyshev. Setelah desain untuk tampilan awal selesai dibuat, maka langkah selanjutnya adalah merancang kode-kode untuk masuk ke dalam tampilan selanjutnya. Kode-kode yang sudah dirancang dimasukkan ke dalam editor. Editor adalah tempat dimana kode-kode dituliskan. Setelah selesai maka file di simpan dengan nama tampilan awal dengan format fig. kemudian Matlab secara otomatis akan membuatkan sebuah m-file. Tahap selanjutnya merancang sebuah tampilan untuk respon magnitude filter pada program GUI blank, setelah selesai membuat tampilan respon magnitude. Langkah selanjutnya adalah merancang kode-kode untuk dimasukkan ke dalam editor. Setelah selesai maka file di simpan. Kemudian tahap terakhir adalah merancang tampilan untuk desain rangkaian Low Pass Filter (LPF), High Pass Filter (HPF), Band Pass Filter (BPF), dan Band Stop Filter (BSF) serta menampilkan nilai prototype, dan scaling. Setelah selesai tahap selanjutnya adalah membuat rangkaian desain LPF, HPF, BPF, dan BSF dengan format jpg, serta mempersiapkan tabel prototype dan rumus scaling. Kemudian merancang kode-kode sesuai dengan bahan-bahan tersebut, kode-kode yang sudah dirancang dimasukkan kedalam editor. jika telah selesai file disimpan. Kemudian seluruh tampilan yang dibuat dilakukan pengujian untuk memastikan bahwa program yang dirancang 
sudah sesuai. Jika seluruh tampilan dapat bekerja dan sesuai dengan yang diharapkan, maka perancangan selesai.

\subsection{Perhitungan Nilai scaling induktor (L) dan kapasitor (C)}

Contoh perhitungan nilai scaling induktor (L) dan kapasitor (C) untuk low pass filter (LPF) dan high pass filter (HPF) dijelaskan sebagai berikut:

\subsubsection{Low pass filter (LPF)}

Proses scaling untuk mendapatkan nilai komponen kapasitor (C) dan induktor (L), dengan orde 2 , ripple $0.01-\mathrm{dB}$, nilai $\mathrm{C}_{\mathrm{n}}$ dan $\mathrm{L}_{\mathrm{n}}$ (nilai $\mathrm{C}$ dan $\mathrm{L}$ prototype) 1.347 dan $1.483, f C=100$ $\mathrm{MHz}$ dan $\mathrm{R}_{\text {load }} 2$ ohm, maka didapat nilai kapasitor $(\mathrm{C})$ dan induktor ( $\mathrm{L}$ ) yaitu :

$$
\begin{aligned}
& \mathrm{C}_{1}=\frac{C 1(\text { prototype })}{2 * \pi . f \text { c. }}=\frac{1.347}{2 * 3,14 * 100.10^{6} * 2}=10.719 \mathrm{nF} \\
& \mathrm{L}_{2}=\frac{R . L 2(\text { prototype })}{2 . \pi . f c .}=\frac{2 * 1.483}{2 * 3,14 * 100.10^{6}}=47.2 \mathrm{nH}
\end{aligned}
$$

Maka rangkaian low pass filter (LPF) dapat dilihat pada $\mathrm{Rs} / \mathrm{RI}=1$ seperti ditunjukan pada Gambar 2.

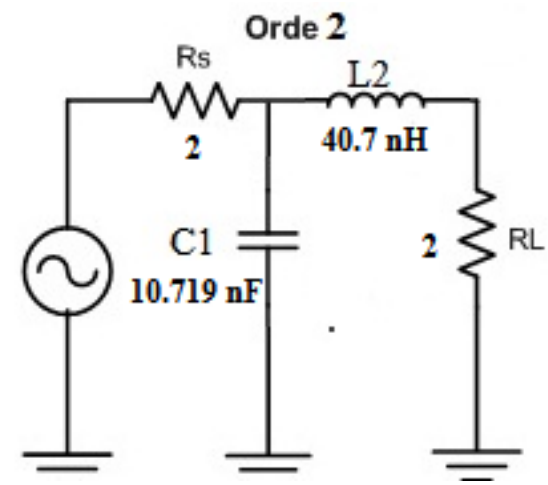

\section{Gambar 2. Realisasi low pass filteryang dirancang}

\subsubsection{High Pass Filter (HPF)}

Tranformasi dari low pass filter prototype menjadi high pass filter prototype dilakukan dengan mengubah nilai pada low pass filter prototype. Jika diketahui pada orde 3 dengan ripple $0,01-\mathrm{dB}$, nilai $\mathrm{C}_{1}=1,181, \mathrm{~L}_{2}=1,483$ dan $\mathrm{C}_{3}=1,181$ (nilai $\mathrm{C}$ dan $\mathrm{L}$ prototype), $f C=100$ $\mathrm{MHz}$ dan $\mathrm{R}_{\text {load }} 2$ dengan $\mathrm{Rs} / \mathrm{RL}=1$, maka dari rumus transformasi yang digunakan didapat hasil $L_{1}=\frac{1}{C 1}=0,84674, C_{2}=\frac{1}{L 2}=0,549149$, dan $L_{3}=\frac{1}{C 3}=0,84674$. Sehingga didapat nilai kapasitor (C) dan induktor $(\mathrm{L})$ adalah :

$$
\begin{aligned}
& \mathrm{L}_{1}=\frac{R . L 1(\text { prototype })}{2 . \pi . f c .}=\frac{1 * 0.846}{2 * 3,14 * 100.10^{6}}=2,69 \mathrm{nF} \\
& \mathrm{C}_{2}=\frac{\text { C2(prototype })}{2 * \pi . f . R}=\frac{0.549}{2 * 3,14 * 100.10^{6} * 1}=43,6 \mathrm{nH} \\
& \mathrm{L}_{3}=\frac{R . L 3(\text { prototype })}{2 . \pi . f c .}=\frac{1 * 0.846}{2 * 3,14 * 100.10^{6}}=2,69 \mathrm{nF}
\end{aligned}
$$

Maka jika ingin merancang HPF, rangkaian dapat dilihat pada gambar 3. 


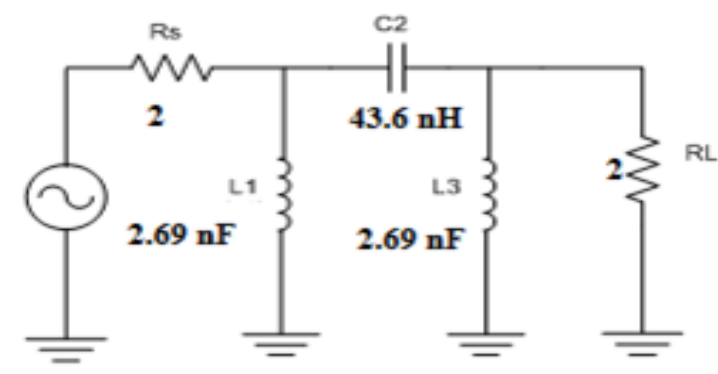

Gambar 3. Realisasi high pass filteryang dirancang

\section{HASI L DAN PEMBAHASAN}

\subsection{Hasil pengujian dan analisis simulasi Low Pass Filter}

Pada simulasi untuk Low Pass Filter, High pass filter, band pass filter, dan band stop filter digunakan menu simulasi untuk mendapatkan respon Chebyshev yang dibuat dengan eksekusi program simulasi pada Matlab versi 7.9

\subsubsection{Simulasi respon Chebyshev pada Low Pass Filter}

Simulasi Respon Low Pass Filter Chebyshev 1 pada Orde 3 ditunjukan pada gambar 4.

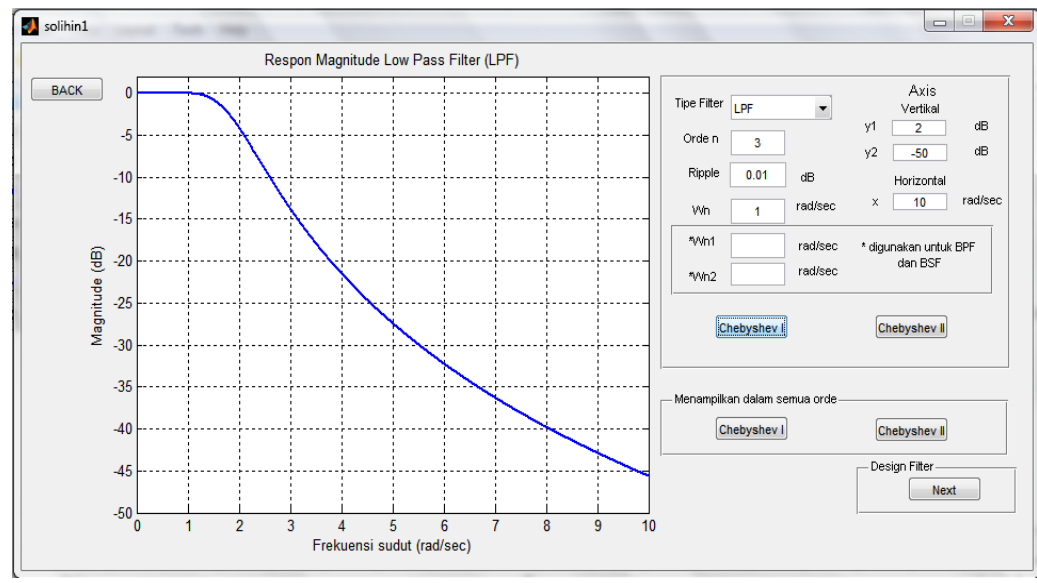

Gambar 4. Respon Low Pass Filter Chebyshev 1 pada Orde 3

Dari hasil simulasi tersebut didapatkan respon low pass filter dengan roll-off yang curam. Ripple hanya diijinkan pada daerah pass band dari frekuensi $0 \mathrm{rad} / \mathrm{s}$ sampai $1 \mathrm{rad} / \mathrm{s}$, amplitudo sinyal turun sebesar $0.01-\mathrm{dB}$ di frekuensi $1 \mathrm{rad} / \mathrm{s}$, dan stop band dari frekuensi 1 $\mathrm{rad} / \mathrm{s}$ sampai nilai maksimum.

\subsubsection{Simulasi nilai kapasitor dan induktor Low Pass Filter}

Parameter input untuk simulasi low pass filter yang ditunjukkan pada gambar 5 adalah :

Tipe Filter : LPF

Ripple : :0,01-dB

Orde $\mathrm{n} \quad: 3$

Rs/Rl $\quad: 1,000$

$\mathrm{f}_{\mathrm{c}} \quad: 3 \mathrm{kHz}$

$\mathrm{R}_{\text {load }} \quad: 1 \Omega$ 


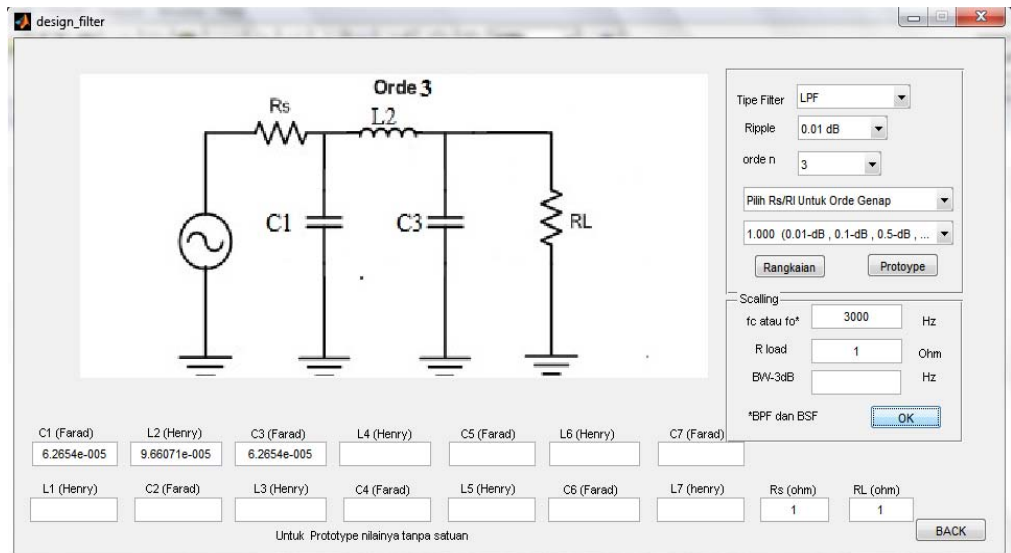

Gambar 5. Scaling Nilai induktor (L) dan kapasitor (C) Low Pass Filter

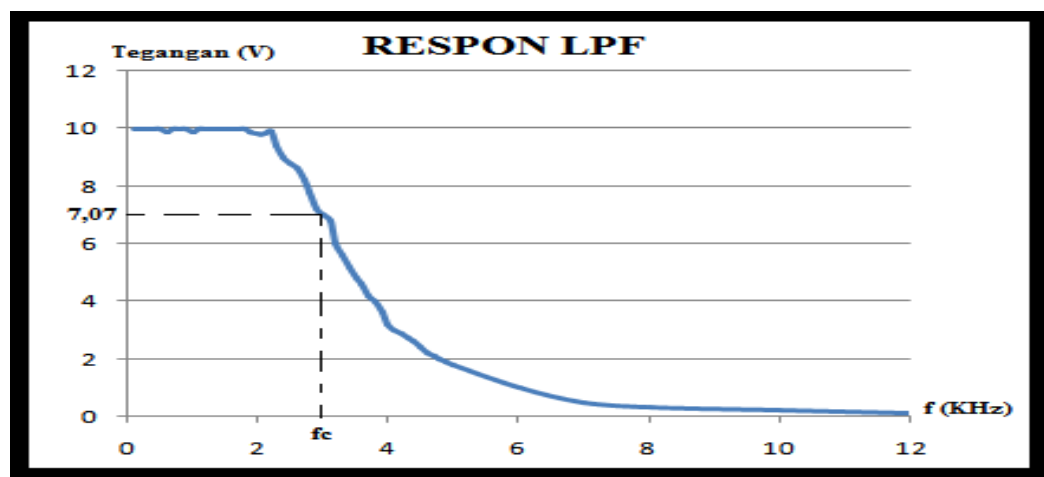

Gambar 6. Respon low pass filter menggunakan electronic workbench (EWB)

Hasil simulasi menggunakan perangkat lunak electronic workbench (EWB) yang ditunjukkan pada Gambar 6, didapatkan respon low pass filter dengan frekuensi cut-off $3 \mathrm{kHz}$ dan tegangan sebesar 7,07 volt atau magnitude sebesar $1 / \sqrt{2} \mathrm{~V}_{\text {in }}$.

\subsubsection{Simulasi respon Chebyshev pada High Pass Filter}

Simulasi respon high pass filter chebyshev 1 pada orde 3 ditunjukkan pada gambar 7.

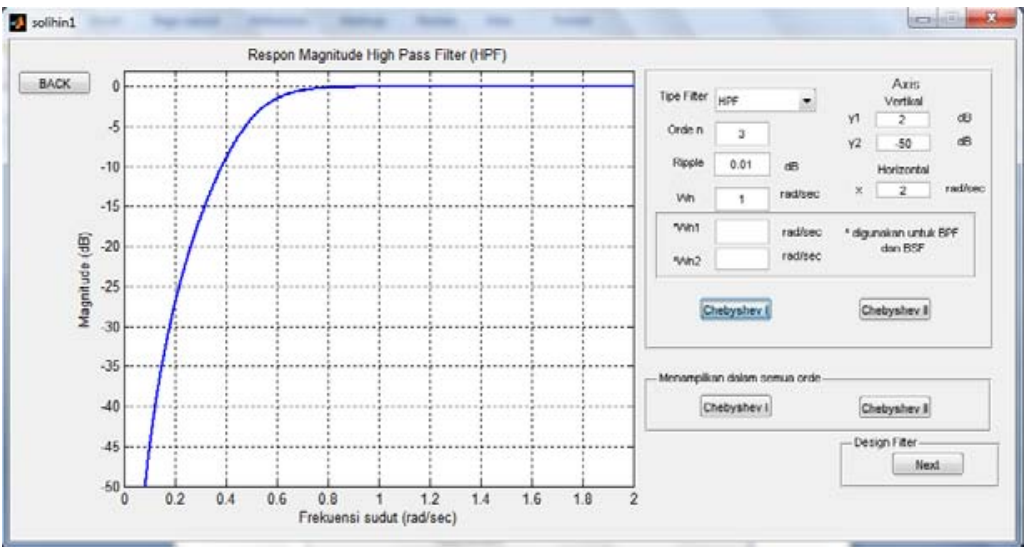

Gambar 7. Simulasi respon high pass filter chebyshev 1 pada orde 3

Hasil simulasi tersebut memperlihatkan respon High Pass Filter dengan stop band dari frekuensi $0 \mathrm{rad} / \mathrm{s}$ sampai $1 \mathrm{rad} / \mathrm{s}$, frekuensi cut-off $1 \mathrm{rad} / \mathrm{s}$, dan pass band frekuensi $1 \mathrm{rad} / \mathrm{s}$ sampai maksimum. 


\subsubsection{Simulasi nilai kapasitor dan induktor High Pass Filter}

Parameter input untuk simulasi high pass filter yang ditunjukkan pada gambar 8 adalah :

$\begin{array}{ll}\text { Tipe Filter } & : \text { HPF } \\ \text { Ripple } & : 0,01-\mathrm{dB} \\ \text { Orde } \mathrm{n} & : 3 \\ \text { Rs/RI } & : 1,000 \\ \mathrm{f}_{\mathrm{c}} & : 3 \mathrm{kHz} \\ \mathrm{R}_{\text {load }} & : 1 \Omega\end{array}$

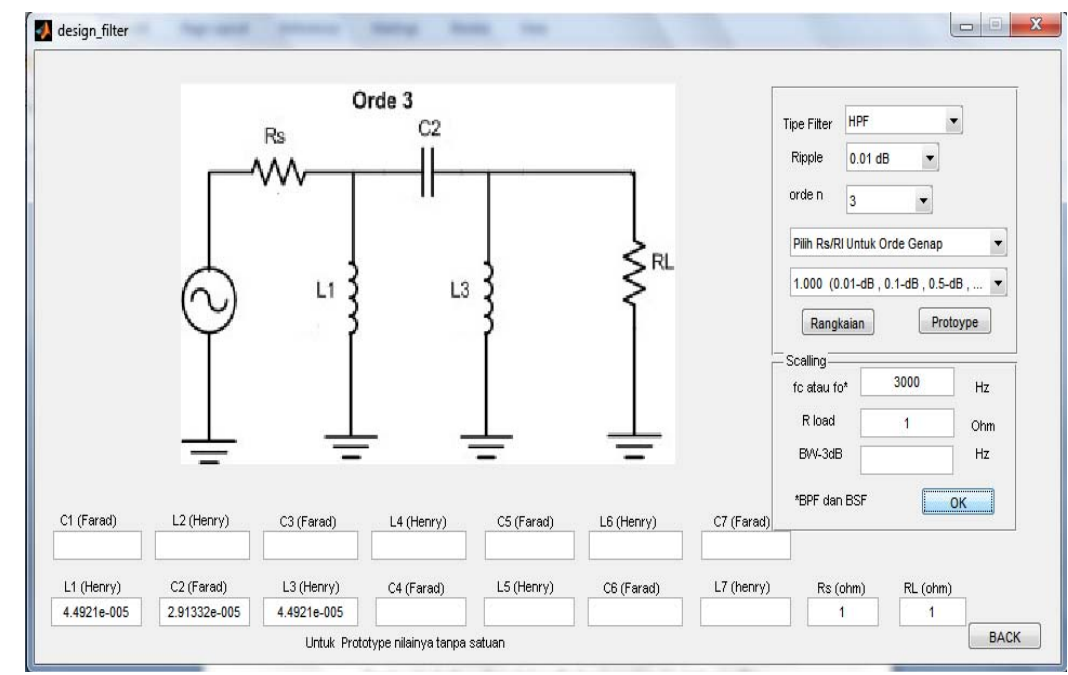

Gambar 8. Scaling Nilai induktor (L) dan kapasitor (C) High Pass Filter

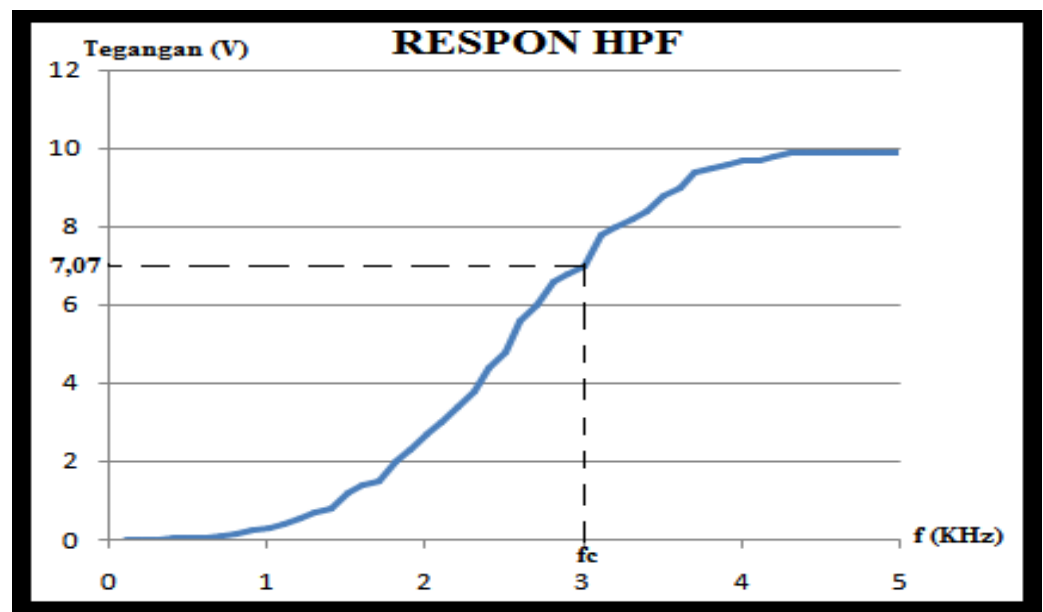

Gambar 9. Respon high pass filter

Dari hasil simulasi menggunakan perangkat lunak eelectronic workbench (EWB) yang ditunjukkan pada Gambar 9 didapatkan respon High pass filter dengan frekuensi cutoff $3 \mathrm{kHz}$, dan magnitude mencapai maksimum sebesar 10 volt pada frekuensi maksimum.

\subsubsection{Simulasi respon Chebyshev pada Band Pass Filter}

Simulasi respon band pass filter chebyshev 1 pada orde 4 ditunjukkan pada gambar 10 . 


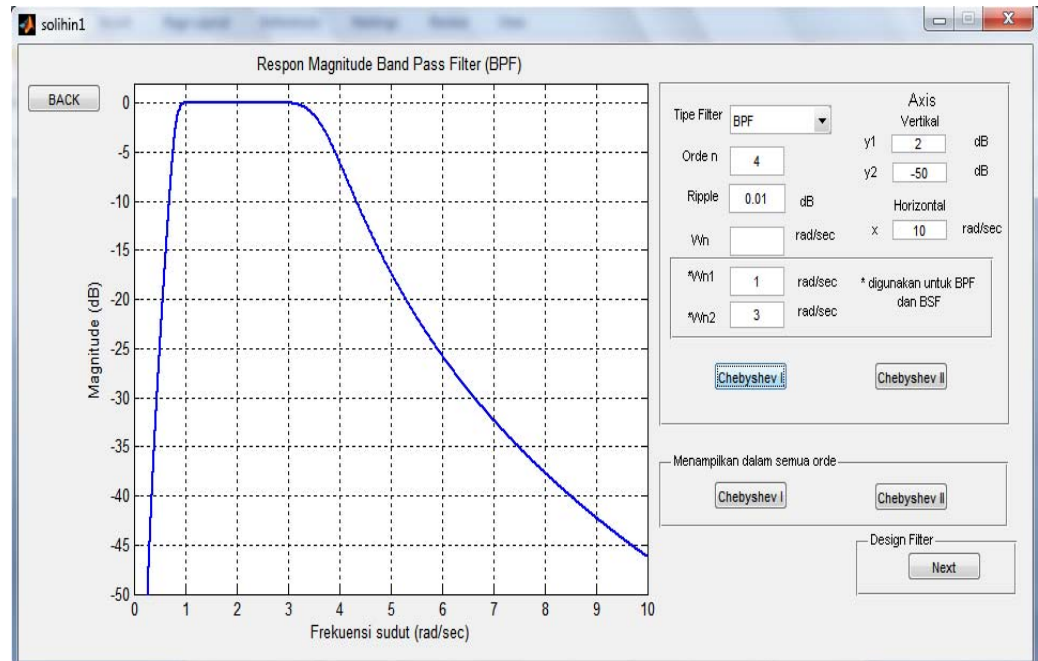

Gambar 10. Respon band pass filter chebyshev 1 pada orde 4

Dari hasil simulasi tersebut didapatkan respon Band Pass Filter dengan frekuensi cut-off pada $\omega_{n 1}=1 \mathrm{rad} / \mathrm{s}$ (frekuensi cut-off 1 ) dan $\omega_{\mathrm{n} 2}=3 \mathrm{rad} / \mathrm{s}$ (frekuensi cut-off 2) dengan ripple sebesar 0,01-db pada pass band, daerah frekuensi dibawah $\omega_{n 1}$ mempunyai roll off yang curam. Sedangkan untuk daerah frekuensi diatas $\omega_{\mathrm{n} 2}$ mempunyai respon yang landai.

\subsubsection{Simulasi nilai kapasitor dan induktor Band Pass Filter}

Parameter input untuk simulasi band pass filter yang ditunjukkan pada gambar 11.

$\begin{array}{ll}\text { Tipe Filter } & : \text { BPF } \\ \text { Ripple } & : 0,01-\mathrm{dB} \\ \text { Orde } \mathrm{n} & : 4 \\ \text { Rs/RI } & : 1,000 \\ \mathrm{f}_{\mathrm{O}} & : 3 \mathrm{kHz} \\ \mathrm{R}_{\text {load }} & : 1 \Omega \\ \text { BW }_{-3 \mathrm{~B}} & : 2 \mathrm{kHz}\end{array}$

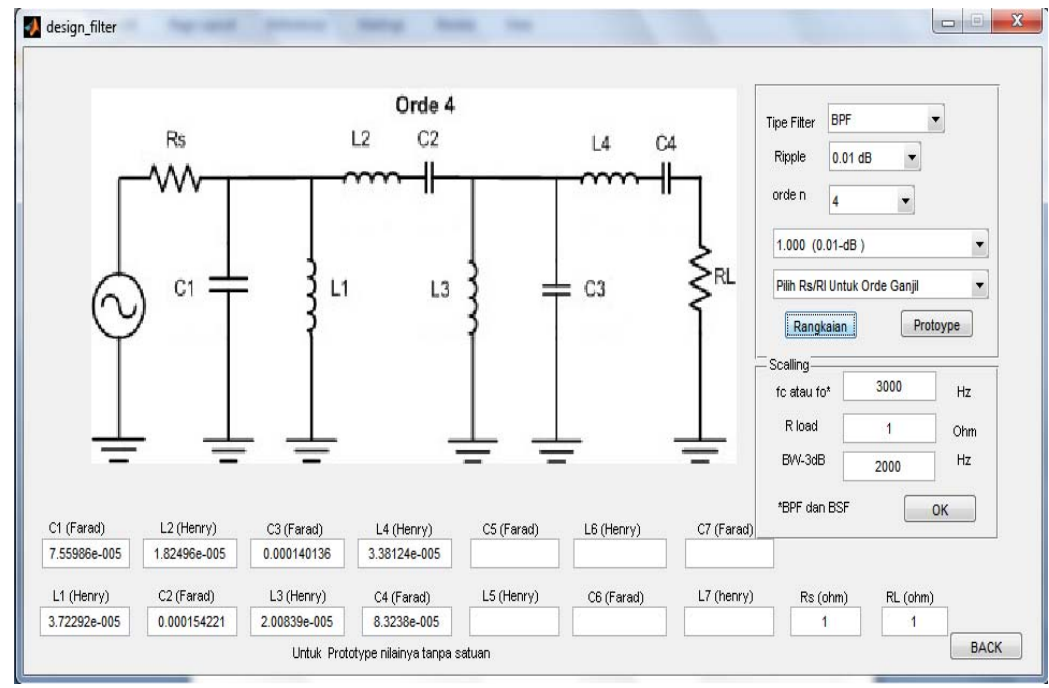

Gambar 11. Scaling Nilai induktor (L) dan kapasitor (C) band Pass Filter 


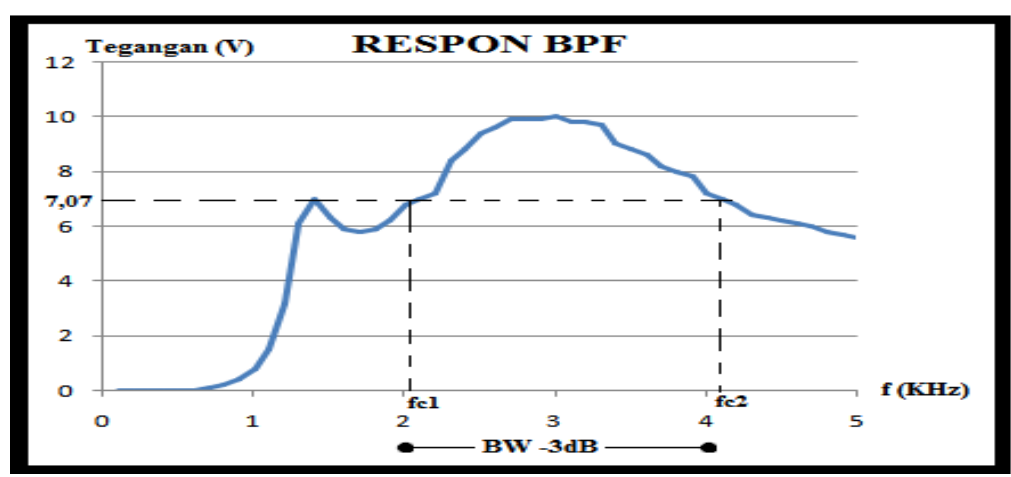

Gambar 12. Respon band pass filtermenggunakan electronic workbench (EWB)

Dari hasil simulasi menggunakan perangkat lunak electronic workbench (EWB) yang ditunjukkan pada Gambar 12 didapatkan respon band pass filter kurang sesuai yang

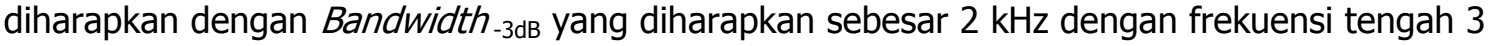
$\mathrm{kHz}$, didapatkan pada simulasi frekuensi cut-off $12,1 \mathrm{kHz}$ dan frekuensi cut-off $24,1 \mathrm{kHz}$, dengan roll off yang curam untuk daerah frekuensi dibawah $2,1 \mathrm{kHz}$, pada frekuensi 1,4 $\mathrm{kHz}$ terdapat sebuah ripple yang merupakan ciri dari respon chebyshev. respon yang landai dengan magnitude menuju $0 \mathrm{~V}$ untuk daerah frekuensi diatas $4,1 \mathrm{kHz}$ (frekuensi cut-off 2) hingga frekuensi maksimum, Bandwidth yang diperoleh dari hasil simulasi menggunakan electronic workbench (EWB) sama dengan yang diharapkan yaitu sebesar $2 \mathrm{kHz}$. Pergeseran nilai bandwidth sebesar $0,1 \mathrm{kHz}$ lebih tinggi disebabkan oleh nilai komponen dan ripple pada respon frekuensi.

\subsubsection{Simulasi nilai kapasitor dan induktor Band Stop Filter}

Simulasi band stop filter chebyshev 1 pada orde 4 ditunjukkan pada gambar 13.

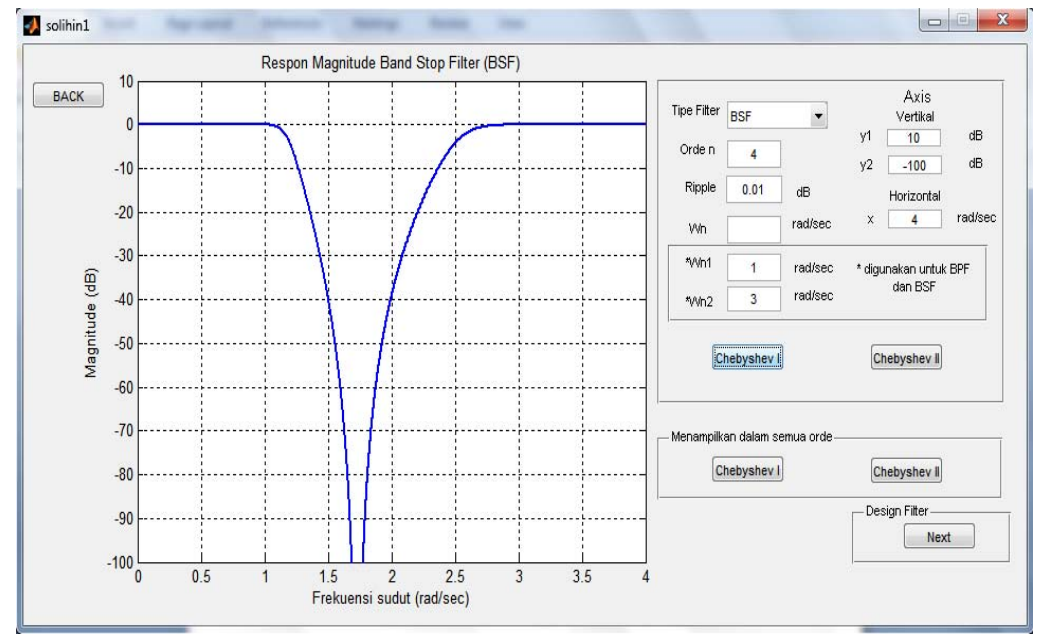

Gambar 13. Respon band stop filter chebyshev 1 pada orde 4

Dari hasil simulasi tersebut didapatkan respon Band Stop Filter dengan frekuensi cut-off $\omega_{\mathrm{n} 1}$ $=1 \mathrm{rad} / \mathrm{s}$ (frekuensi cut-off 1 ) dan $\omega_{\mathrm{n} 2}=3 \mathrm{rad} / \mathrm{s}$ (frekuensi cut-off 2), daerah frekuensi $\omega_{\mathrm{n} 1}$ mempunyai roll off yang curam dan untuk daerah frekuensi dibawah $\omega_{\mathrm{n} 2}$ juga mempunyai roll off yang curam.

\subsubsection{Simulasi nilai kapasitor dan induktor Band Stop Filter}

Parameter input untuk simulasi band stop filter yang ditunjukkan pada gambar 14 adalah : 


$\begin{array}{ll}\text { Tipe Filter } & : \text { BSF } \\ \text { Ripple } & : 0,01-\mathrm{dB} \\ \text { Orde } \mathrm{n} & : 4 \\ \mathrm{Rs} / \mathrm{Rl} & : 1,000 \\ \mathrm{f}_{\mathrm{o}} & : 3 \mathrm{kHz} \\ \mathrm{R}_{\text {load }} & : 1 \Omega \\ \mathrm{BW}_{-3 \mathrm{~B}} & : 2 \mathrm{kHz}\end{array}$

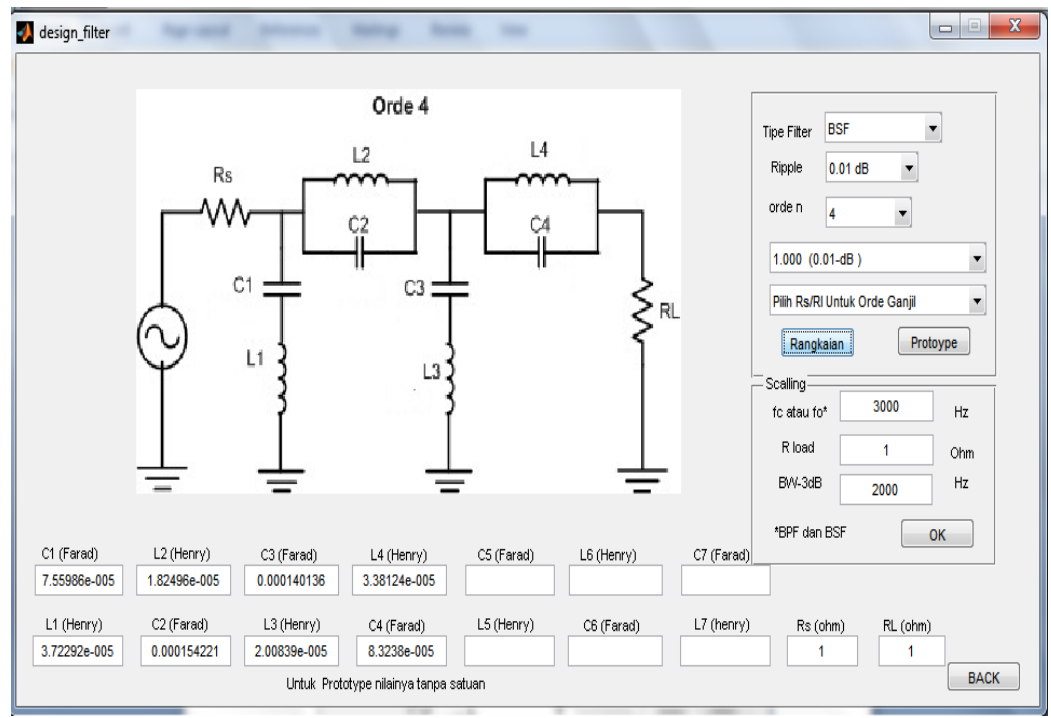

Gambar 14. Scaling Nilai induktor (L) dan kapasitor (C) band stop Filter

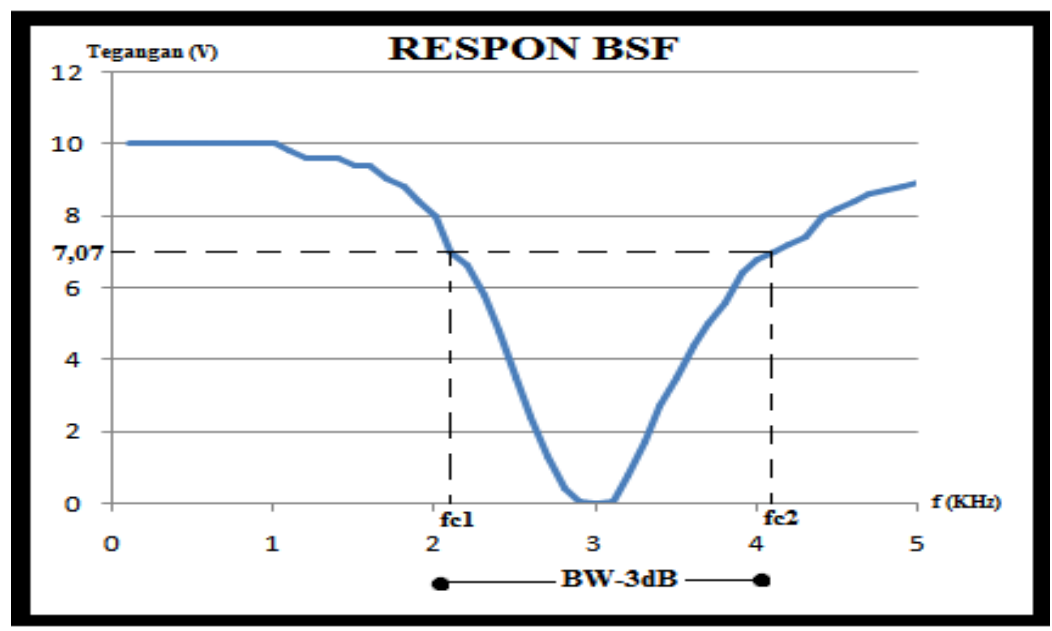

Gambar 15. Respon band stop filtermenggunakan electronic workbench (EWB)

Dari hasil simulasi menggunakan perangkat lunak electronic workbench (EWB) yang ditunjukkan pada gambar 15 didapatkan respon band stop filter kurang sesuai dengan Bandwidth $_{3 \mathrm{~dB}}$ yang diharapkan adalah sebesar $2 \mathrm{kHz}$ dengan frekuensi tengah $3 \mathrm{kHz}$ didapatkan frekuensi cut-off $12,1 \mathrm{kHz}$ dan frekuensi cut-off $24,1 \mathrm{kHz}$, Bandwidth yang diperoleh dari hasil simulasi menggunakan perangkat lunak electronic workbench (EWB) sama dengan yang diharapkan yaitu sebesar $2 \mathrm{kHz}$. Pergeseran bandwidth sebesar $0,1 \mathrm{kHz}$ lebih tinggi disebabkan oleh nilai komponen dan ripple pada respon frekuensi. 


\section{KESI MPULAN}

Setelah melakukan pengujian dan analisis dari simulasi perancangan filter analog dengan respon Chebyshev menggunakan Matlab versi 7.9, diperoleh kesimpulan sebagai berikut :

1. Pada simulasi untuk mendapatkan respon Chebyshev pada low pass filter, high pass filter, band pass filter, dan band stop filter hasilnya sesuai dengan yang diharapkan dan sesuai dengan teori respon filter Chebyshev.

2. Perancangan simulasi rangkaian filter, nilai induktor (L) dan kapasitor (C) dari band pass filter dan band stop filter memiliki nilai protype yang sama untuk semua orde, tetapi scaling memiliki nilai yang berbeda.

3. Pada simulasi respon band pass filter, dan band stop filter menggunakan Electronic Workbench (EWB) dengan desain filter dari scaling didapatkan nilai batas bandwidth yang mengalami pergeseran sebesar $0,1 \mathrm{kHz}$ lebih tinggi dari nilai batas bandwidth yang diharapkan.

\section{DAFTAR RUJ UKAN}

Bowick, Chris. (1982). RF Circuit Design. Indianapolis : Howard W. Sam \& Co.,Inc. Leonard Tampubolon, (2012), Perancangan Simulasi Dengan Respon Butterworth Menggunakan Matlab Versi 7.9. Bandung : Institut Teknologi Nasional Bandung.

Steven. (1997). The Scientist and Engineer's Guide to Digital Signal Processing. California : California Technical

Sugiharto, Aris. (2006). Pemrograman Dengan Matlab. Yogyakarta : Penerbit Andi.

Saputro, Wahyu Hadi. (2009). Analog dan Digital Filter Menggunakan Matlab. 